Original Research Paper

\title{
Komposisi Jenis Makroalga di Perairan Pulau Hari Sulawesi Tenggara (Spesies Composition of Makroalga in Hari Island, South East Sulawesi)
}

\author{
$\operatorname{Ira}^{1^{*}}$, Rahmadani $^{1}$, Nur Irawati $^{1}$ \\ ${ }^{1}$ Fakultas Perikanan dan Ilmu Kelautan Universitas Halu Oleo
}

\author{
Article history \\ Received: 03 Agustus 2018 \\ Revised: 20 September 2018 \\ Accepted: 04 November 2018 \\ Published: 21 November 2018 \\ *Corresponding Author: \\ Ira, Fakultas Perikanan dan \\ Ilmu Kelautan Universitas \\ Halu Oleo, Indonesia; \\ Email: \\ irafpikunhalu@gmail.com
}

\begin{abstract}
Makroalga is a large algae with a thallus body structure and has a chlorophy 11 pigment. Macroalga has an important role in marine waters both ecologically and economically. This study aims to provide information about the diversity of macroalgae in the waters of the Hari Island and the wealth of macroalgae in South East Sulawesi. The study was conducted in the waters of Hari Island, South East Sulawesi from mei to juli 2016. The observation was done by observing all types of macroalgae found in the area traversed. The results of the study found that the number of macroalgae species consisted of 25 species consisting of 11 orders, 14 families, 17 genera. The species composition was dominated by chlorophyta class (44\%), rhodophyta class $(28 \%)$ and phaeophyta class $(28 \%)$. The water quality of Hari Island waters is still within the range that supports macroalgae growth.
\end{abstract}

Keywords: Composition, macroalgae, Hari Island

Abstrak: Makroalga merupakan alga yang berukuran besar dengan struktur tubuh berupa thallus dan memiliki pigmen klorofil. Makroalga memiliki peranan penting di perairan laut baik secara ekologi maupun ekonomi. Penelitian ini bertujuan untuk memberikan informasi tentang keanekaragaman jenis makroalga di perairan Pulau Hari, sehingga diharapkan dapat memberikan gambaran kekayaan makroalga di Sulawesi Tenggara. Penelitian dilaksanakan di perairan Pulau Hari Kabupaten Konawe Selatan pada bulan mei-juli 2016. Pengamatan dilakukan dengan sistim jelajah yaitu mengamati semua jenis makroalga yang ditemukan pada area yang dilalui. Hasil penelitian jumlah jenis makroalga yang ditemukan terdiri atas 25 spesies yang meliputi 11 ordo, 14 famili, 17 genus. Komposisi jenis didominasi oleh kelas Chlorophyta (44\%), kelas Rhodophyta (28\%) dan kelas Phaeophyta (28\%). Kualitas air di perairan Pulau Hari masih berada dalam kisaran yang mendukung pertumbuhan makroalga.

Kata kunci: Komposisi jenis, makroalga, pulau hari

\section{Pendahuluan}

Sulawesi Tenggara merupakan salah satu propinsi di Indonesia yang memiliki panjang garis pantai $\pm 1.740 \mathrm{~km}$ dan terdiri dari sekitar 124 buah pulau-pulau kecil serta memiliki luas wilayah lautan sekitar $\pm 110.000 \mathrm{~km}^{2}$ (Statistik Daerah Propinsi Sulawesi Tenggara, 2017). Perairan Sulawesi Tenggara juga memiliki berbagai biota laut baik flora maupun fauna yang mempunyai nilai potensial dan peranan penting, baik secara ekologi maupun ekonomi.

Makroalga merupakan bagian dari flora yang terdiri atas banyak jenis dan memiliki peranan penting di lingkungan laut. Makroalga adalah alga yang berukuran besar, dari beberapa centimeter (cm) sampai bermeter-meter. Alga termasuk dalam Kingdom Protista mirip dengan tumbuhan, dengan struktur tubuh berupa talus dan memiliki pigmen klorofil sehingga dapat berfotosintesis (Tjitrosoepomo, 2005)

Peranan penting keberadaan makroalga di perairan laut antara lain sebagai organisme produser yang bermanfaat bagi kehidupan organisme, terutama organisme-organisme herbivora. Berperan sebagai penyedia karbonat dan pengokoh substrat dasar sehingga bermanfaat bagi stabilitas dan kelanjutan keberadaan terumbu 
karang (Wray, 1977). Sebagaimana menurut Dawson (1966) bahwa makroalga (marga Calcareous) memilikikandungan kalsit dan aragonit yang dapat membentuk semen sebagai perekat pecahan karang mati, sehingga dapat bermanfaat untuk ketahanan terhadap benturan ombak besar. Makroalga dapat pula berperan dalam menunjang kebutuhan hidup manusia yakni sebagai bahan pangan dan industri (Angka dan Suhartono, 2000)

Berdasarkan pentingnya peranan makroalga, maka perlu dilakukan pendataan atau inventarisasi makroalga di berbagai perairan laut di Indonesia, salah satunya di perairan Pulau Hari. Pulau Hari merupakan sebuah pulau kecil yang tidak berpenghuni. Sebagian besar pulau ini merupakan batu-batuan yang ke arah laut membentuk tebing yang terjal, yaitu pada bagian utara dan selatan, sementara sisi sebelah timur dan barat merupakan hamparan pasir putih. Pulau Hari telah dijadikan sebagai tempat objek wisata bahari oleh pemerintah
Sulawesi Tenggara karena keindahan alam lautnya. Namun, potensi alamnya masih banyak belum terekspos terutama keberadaan makroalganya. Oleh karena itu, penelitian ini dapat menyajikan data dan informasi mengenai keanekaragaman jenis makroalga di Perairan Pulau Hari. Sehingga diharapkan dapat memberikan gambaran sebagian kekayaan makroalga di Sulawesi Tenggara.

\section{Bahan dan Metode}

\section{Waktu Dan Tempat}

Penelitian dilakukan di perairan intertidal Pulau Hari Kabupaten Konawe Selatan Sulawesi Tenggara (S $04^{\circ} 02.270^{\prime}$ dan E $122^{\circ} 46.555^{\prime}$ )dan identifikasi sampel di lakukan di Laboratorium Fakultas Perikanan Dan Ilmu Kelautan Universitas Halu Oleo Kendari. Penelitian ini berlangsung selama \pm tiga bulan yaitu Mei-Juli 2016.

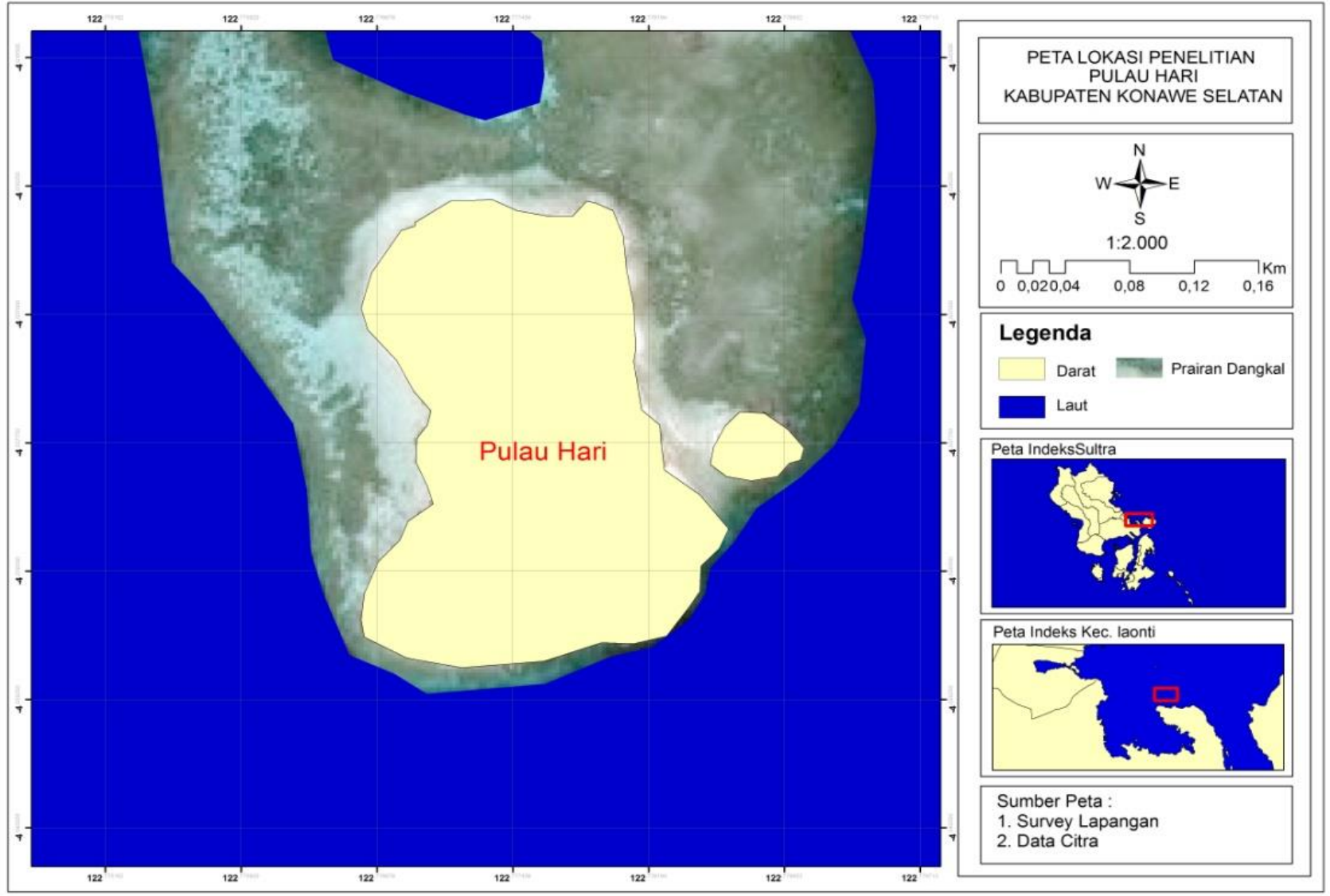

Gambar 1. Lokasi penelitian di Pulau Hari Sulawesi Tenggara 


\section{Pengambilan Sampel Makroalga dan Identifikasi}

Pengambilan sampel makroalga dilakukan saat air laut surut. Pengamatan dilakukan dengan sistim jelajah dengan penyelaman/snorkling yaitu mengamati semua jenis makroalga yang ditemukan pada area yang dilalui. Sampel yang didapat dibersihkan dari substratnya, didokumentasikan dan dimasukan ke dalam kantong sampel yang telah diberi label dan disimpan di cool box. Selanjutnya dibawa ke laboratorium untuk diidentifikasi. Variabel yang diamati adalah ciri morfologi makroalga yang meliputi daun, batang, akar. Identifikasi makroalga menggunakan panduan www.algabase.org.

\section{Pengukuran Parameter Kualitas Air}

Selain itu dilakukan juga pengukuran parameter lingkungan yang meliputi parameter fisika dan kimia yaitu suhu (termometer), salinitas (handrefractometer), $\mathrm{pH}$ ( $\mathrm{pH}$ indikator), nitrat dan fosfat (spectrofotometer), kecerahan (sechi disk), kedalaman perairan (tiang berskala) dan kecepatan arus (floating dredge). Pengukuran tersebut dilakukan bersamaan dengan pengambilan sampel makroalga.

\section{Analisis Data}

Semua data makroalga yang dikumpulkan dianalisis secara tabulasi dan ditampilkan dalam bentuk tabel dan gambar

\section{Hasil dan Pembahasan}

Hasil

Makroalga yang ditemukan selama penelitian sebanyak 11 ordo, 14 famili, 17 genus dan 25 spesies yang terdiri atas kelas chlorophyta, rhodophyta dan phaeophyta. Nilai ini termasuk dalam kategori tinggi apabila dibandingkan dengan beberapa hasil penelitian yang pernah dilakukan, Fadhillah (2009), menemukan sekitar 16 spesies makroalga di perairan Pantai Lakeba, Fitriah (2001) menemukan 17 spesies di perairan pantai bagian barat Desa Torokeku, Umasagi (2001) menemukan 19 spesies di perairan pantai Desa Tanjung Tiram. Tingginya jumlah spesies makroalga yang ditemukan di Pulau Hari disebabkan oleh kondisi substratnya yang bervariasi (substrat pasir-pecahan karang, pasir-karang hidup, dan rataan terumu) dibandingkan yang daerah lainnya. Hal ini didukung oleh pernyataan Kadi (2000), bahwa kehadiran makroalga menunjukkan bahwa kombinasi struktur substrat sangat menentukan variasi spesies makroalga yang ada.

Kondisi substrat di Pulau Hari, yaitu daerah tepi pantainya, memiliki substrat pasir-pecahan karang mati; kearah tengah, pasir-karang hidup dan hamparan lamun; kearah tubir, rataan terumbu karang. Sementara penelitian Fadhillah (2009), kondisi substratnya berpasir yang didominasi oleh batu; Fitriah (2001), kondisi substratnya hanya didominasi oleh pasir; Umasagi (2001), terdiri atas substrat pasir sangat kasar dan pecahan karang maupun cangkang moluska.

Perbedaan jumlah spesies makroalga juga dipengaruhi oleh faktor kondisi lingkungan yang mendukung kemampuan adaptasi dari masingmasing spesies. Sebagaimana pernyataan McNaughton dan Wolf (1990), bahwa perbedaan jumlah spesies makroalga dipengaruhi oleh beberapa faktor diantaranya, daya reproduksi yang tinggi, kemampuan adaptasi yang berkembang, daya tahan yang lemah terhadap habitat, adanya predator dan penyakit. Faktor kondisi lingkungan di Pulau Hari masih mendukung untuk pertumbuhan makroalga. Jenis makroalga yang ditemukan di Pulau Hari dapat dilihat pada Tabel 1.

Tabel 1. Jenis Makroalga di Perairan Pulau Hari

\begin{tabular}{|c|c|c|c|c|c|}
\hline No & Divisi & Ordo & Famili & Genus & Spesies \\
\hline \multicolumn{6}{|c|}{ Chlorophyta } \\
\hline 1 & & Dasycladales & Halimedaceae & Halimeda & Halimeda renschii \\
\hline 2 & & & & & Halimeda opuntia \\
\hline 3 & & & & & Halimeda macroloba \\
\hline 4 & & & Udoteaceae & Chlorodesmis & Chlorodesmis $s p$ \\
\hline
\end{tabular}




\begin{tabular}{|c|c|c|c|c|c|}
\hline No & Divisi & Ordo & Famili & Genus & Spesies \\
\hline 5 & & & Dasyladaceae & Neomeris & Neomeris annulata \\
\hline 6 & & Cladophorales & Siphonocladaceae & Boergensenia & Boergensenia forbesii \\
\hline 7 & & & Valoniaceae & Dictyosphaeria & Dictyosphaeria cavernosa \\
\hline 8 & & & & Valunia & Valunia macrophysa \\
\hline 9 & & & & & $\underline{\text { Valonia ventricosa }}$ \\
\hline 10 & & Siphonale & Caulerpaceae & Caulerpa & Caulerpa serullata \\
\hline 11 & & & & & Caulerpa lentillifera \\
\hline \multicolumn{6}{|c|}{ Phaeophyta } \\
\hline 1 & & Dictyotales & Dictyotaceae & Padina & Padina minor \\
\hline 2 & & & & & Padina australis \\
\hline 3 & & Fucales & Sargassaceae & Sargassum & Sargassum crassifolium \\
\hline 4 & & & & & Sargassum filipendula \\
\hline 5 & & & & Turbinaria & Turbinaria ornata \\
\hline 6 & & Ectocarpales & Scytosiphonaceae & Hidroclatrus & Hydroclathrus clatratus \\
\hline 7 & & Dictyotales & Dictyotaceae & Dictyota & Dictyota bartayresiana \\
\hline \multicolumn{6}{|c|}{ Rhodophyta } \\
\hline 1 & & Corallinales & Corallinaceae & Amphiroa & Amphiroa fragilissima \\
\hline 2 & & Nemaliales & Galaxauraceae & Galaxaura & Galaxaura regosa \\
\hline 3 & & Gigartinales & Soleriaceae & Eucheuma & Eucheuma cottonii \\
\hline 4 & & & & Gracilaria & Gracilaria salicornia \\
\hline 5 & & & & & Gracilaria edulis \\
\hline 6 & & & & & Gracilaria verrucosa \\
\hline 7 & & Ceramiales & Ceramiceae & Acanthopora & Acanthopora muscoides \\
\hline
\end{tabular}

Makroalga kelas chlorophyta yang paling banyak ditemukan di Pulau Hari dibandingkan dengan kelas rhodophyta dan phaeophyta yakni sebesar 44\%, sementara kelas rhodophyta dan phaeophyta masing-masing sebesar $28 \%$. Tingginya persentase kelas chlorophyta disebabkan karena kondisi substratnya mendukung untuk tumbuh dan berkembang. Sebagian besar makroalga kelas chlorophyta di Pulau Hari ditemukan berada pada daerah pantai dengan substrat pasir-pecahan karang mati dan pasir-karang hidup. Sementara kelas phaeophyta dan rhodophyta kebanyakan ditemukan hanya menempel pada pecahan karang mati atau pecahan karang hidup atau rataan terumbu karang. Hal ini sesuai dengan pernyataan Kadi (1996), bahwa chlorophyta hidupnya menancap atau menempel di substrat yang dasar perairannya seperti karang mati, pasir dan pasir berlumpur. Selanjutnya Odum (1993), menambahkan bahwa alga chlorophyta tersebar di perairan pantai, lebih ke tengah kelas phaeophyta dan lebih dalam lagi rhodophyta. Persentase kelas makroalga yang ditemukan di Pulau Hari dapat dilihat pada Gambar 2

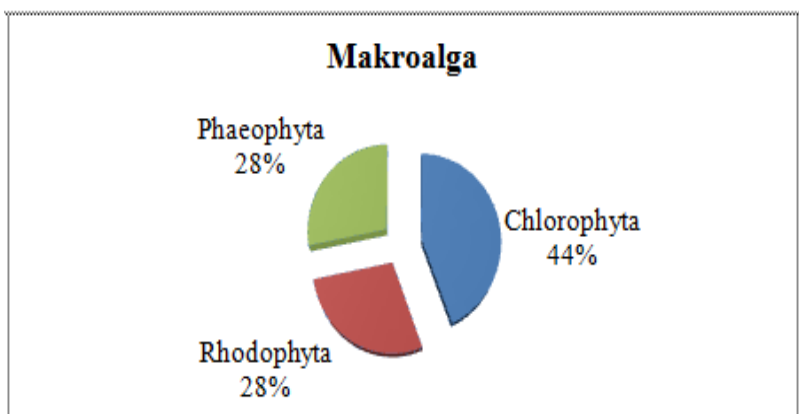

Gambar 2. Persentase kelas makroalga di Pulau Hari

Genus yang paling banyak ditemukan pada kelas chlorophyta adalah Halimeda sebesar 28\%, disusul Caulerpa dan Valunia masing-masing sebesar $18 \%$. Genus yang paling sedikit adalah Dictyosphaeria, Boergensenia, Neomeris dan Chlorodermis masing-masing sebesar $9 \%$. Tingginya genus Halimeda yang ditemukan 
disebabkan karena Halimeda dapat tumbuh pada berbagai substrat karena memiliki kemampuan adaptasi yang cukup tinggi. Holdfast yang dimilikinya yakni berupa kumpulan akar serabut, mampu mengait substrat kasar maupun partikel pasir. Genus Halimeda ditemukan di Pulau Hari berada di daerah pasir, pecahan-pecahan karang mati dan karang hidup.

Kemampuan adaptasi Halimeda yang cukup tinggi tersebut menyebabkan penyebarannya luas. Hal ini sesuai dengan pendapat Morthon (1990), bahwa jenis Halimeda merupakan alga hijau tropis yang paling luas distribusinya. Didukung pula oleh pendapat Atmadja et al (1996), makroalga Halimeda opuntia mempunyai toleransi yang luas terhadap lingkungan, dimana dapat terekspos selama satu hari dan dapat tumbuh pada berbagai substrat. Menurut Kadi dan Wanda (1998), bahwa jenis Halimeda (H. macroloba dan $H$. opuntia) dalam keadaan basah dapat bertahan hidup di atas permukaan air selama satu hari. Genus kelas chlorophyta lainnya seperti Chlorodesmis, Neomeris, Boergensenia, Valunia, Dictyosphaeria,Caulerpa ditemukan hanya menempel pada substrat karang mati atau pasir. Persentase genus pada kelas chlorophyta dapat dilihat pada Gambar 3.

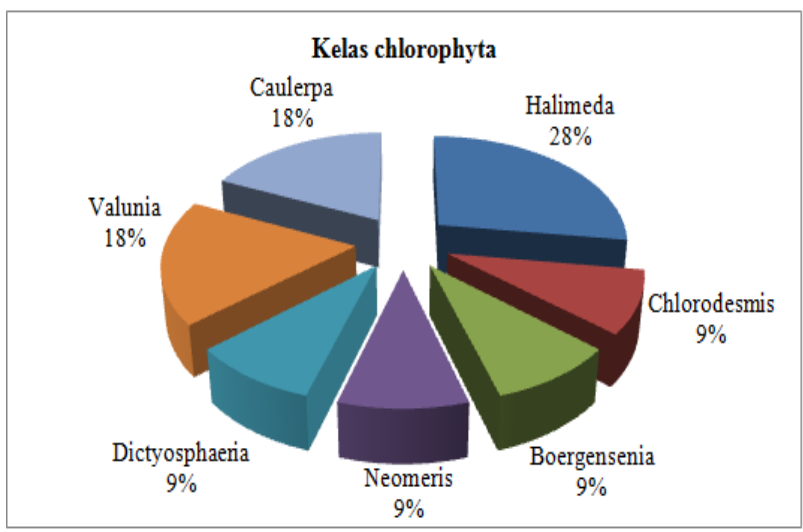

Gambar 3. Persentase genus dari kelas chlorophyta

Genus yang paling banyak ditemukan pada kelas phaeophyta adalah Padina dan Sargassum masing-masing sebesar 29\%. Sementara Turbinaria, Dictyota dan Hidroclatrus masingmasing sebesar $14 \%$. Tingginya genus Padina disebabkan daya adaptasinya yang cukup tinggi terhadap lingkungan. Padina mampu hidup pada berbagai substrat seperti, lumpur berpasir, berlumpur yang dasarnya agak keras, serta menempel pada batu di daerah terumbu baik yang terkena hempasan ombak langsung maupun terlindungi. Menurut Kadi dan Atmadja (1988), habitat Padina (Padina australis) tumbuh menempel pada batu di daerah terumbu baik di tempat-tempat yang terkena hempasan ombak langsung maupun terlindung. Selain itu Padina juga dapat mentolerir keadaan kering yang lama dimana pada jenis lain kurang mampu untuk hidup. Padinayang ditemukan di Pulau Hari kebanyakan pada substrat pasir dan pecahan karang.

Genus Sargassum juga banyak ditemukan di Pulau Hari selain Padina. Genus Sargassum sebagian besar ditemukan menempel pada rataan terumbu. Bentuk holdfastnya yang berbentuk cakram berguna untuk menempel kuat pada substrat, agar tidak terlepas dari substratnya ketika ombak besar. Kelas phaeophyta lainnya yang ditemukan di rataan terumbu adalah Genus Turbinaria, Dictyota dan Hidroclatrus. Makroalga tersebut juga memiliki thallus pengikat substrat yang kuat untuk melindungi diri dari ombak besar dan arus yang deras. Persentase genus pada kelas phaeophyta dapat dilihat pada Gambar 4.

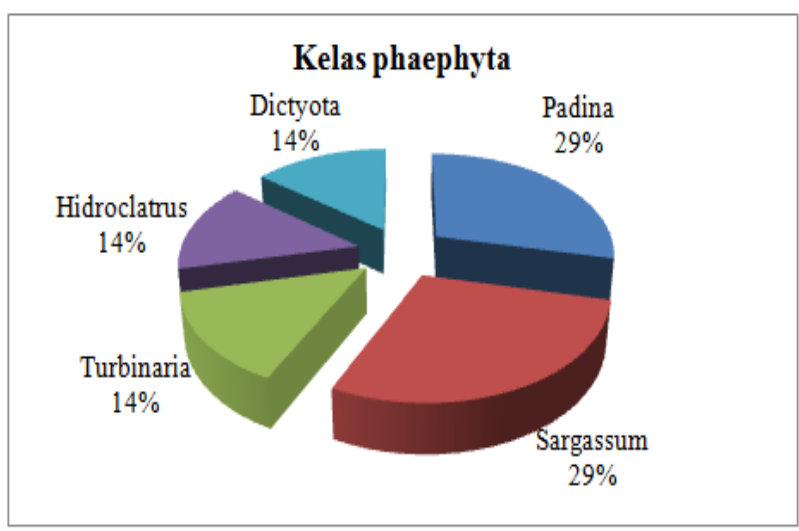

Gambar 4. Persentase genus dari kelas phaeophyta

Genus kelas rhodophyta yang paling banyak ditemukan adalah Gracilaria sebesar $43 \%$ disusul Amphiroa sebesar 15\%. Genus yang paling sedikit adalah Acanthopora, Galaxaura dan Eucheuma masing-masing sebesar $14 \%$. Tingginya genus Gracilaria yang ditemukan disebabkan oleh kemampuan adaptasinya yang cukup tinggi untuk bertahan hidup. Sebagaimana pernyataan Kadi dan Wanda (1998), bahwa Gracilaria (Gracilaria salicornia) dapat pula dalam keadaan basah bertahan hidup di atas permukaan air selama satu hari. Gracilaria yang ditemukan di Pulau Hari 
terdapat di substrat pasir dan pecahan karang mati dan karang hidup. Gracilaria mempunyai thallus yang agak padat dan keras untuk melekat pada substrat.

Genus kelas rhodophta yang ditemukan lainnya adalah Amphiroa ditemukan di substrat pasir, Acanthopora ditemukan di pasir-karang mati, Galaxaura dan Eucheumaditemukan pada substrat rataan terumbu karang. Persentase genus pada kelas rhodophyta dapat dilihat pada Gambar 5.

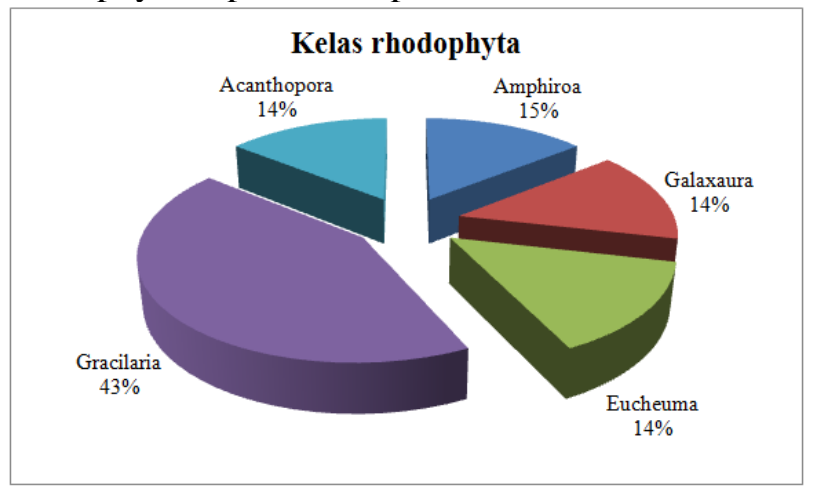

Gambar 5. Persentase genus dari kelas rhodophyta

Kualitas lingkungan perairan juga dapat memberikan pengaruh yang cukup besar terhadap pertumbuhan dan perkembangan makroalga, antara lain suhu, salinitas, $\mathrm{pH}$, nitrat, fosfat, kecerahan, kedalaman perairan serta kecepatan arus. Kualitas lingkungan yang diukur di lokasi penelitian dapat dilihat pada Tabel 2 .

Tabel 2. Kualitas lingkungan di lokasi penelitian

\begin{tabular}{clcc}
\hline No & Parameter lingkungan & Satuan & Kisaran \\
\hline 1. & Suhu & ${ }^{\circ} \mathrm{C}$ & 29 \\
2. & Salinitas & ${ }^{\circ}$ oo & $32-33$ \\
3. & $\mathrm{pH}$ & - & 7 \\
4. & Nitrat & $\mathrm{mg} / \mathrm{l}$ & $0,0127-0,0147$ \\
5. & Fosfat & $\mathrm{mg} / \mathrm{l}$ & $0,0040-0,0044$ \\
6. & Kecerahan & $\%$ & $100 \%$ \\
7. & Kedalaman perairan & $\mathrm{cm}$ & $10-270$ \\
8. & Kecepatan arus & $\mathrm{m} / \mathrm{dtk}$ & $0,021-0,048$ \\
\hline
\end{tabular}

Suhu dapat mempengaruhi pertumbuhan makroalga yaitu pada aktifitas fotosintesis. Apabila suhu tinggi maka aktifitas fotosintesis akan terganggu bahkan terhenti (Hill et al., 2009). Suhu yang terukur di lokasi penelitian berkisar $29^{\circ} \mathrm{C}$. Hal ini masih mendukung pertumbuhan makroalga. Sesuai dengan pernyataan Dawes (1981) bahwa kisaran suhu normal untuk pertumbuhan makroalga adalah 25-35 ${ }^{\circ} \mathrm{C}$ dan didukung oleh pernyataan Toni (2006), suhu tinggi yaitu diatas $30{ }^{\circ} \mathrm{C}$, proses fotosintesis akan berhenti karena pigmen-pigmen fotosintesis mengalami kerusakan (Hill et al., 2009).

Salinitas yang terukur di lokasi penelitian adalah $32-33 \%$. Nilai tersebut masih sesuai untuk makroalga. Menurut Kadi dan Atmadja (1988), alga bentik tumbuh pada perairan dengan salinitas 13-37 $\%$. Salinitas dapat mempengaruhi fisiologi dan laju fotosintesis makroalga (Xiong dan Zhu, 2002).

Nilai $\mathrm{pH}$ yang terukur di lokasi penelitian adalah 7. Hal ini masih sesuai untuk pertumbuhan makroalga. Sebagaimana pernyataan Serdianti dan Widiastuti (2010) bahwa pH yang baik untuk makroalga (rumput laut) dengan tingkat potensi lahan yang sesuai adalah 7-8,5. Hal tersebut didukung pula oleh pernyataan Papalia dan Arfah (2013), kondisi perairan yang bersifat sangat asam maupun sangat basa akan membahayakan kelangsungan hidup organisme karena akan menyebabkan terjadinya gangguan metabolisme dan respirasi. $\mathrm{pH}$ dapat mempengaruhi pertumbuhan makroalga.

Makroalga membutuhkan nitrat dan fosfat sebagai makanan untuk membantu proses fotosintesis. Hasil penelitian diperoleh nitrat berkisar antara $0,0127-0,0147 \mathrm{mg} / \mathrm{l}$ dan nilai fosfat berkisar antara 0,0040-0,0044 mg/l. Nilai tersebut masih mendukung untuk pertumbuhan makroalga. Menurut Effendie (2003), kadar nitrat-nitrogen pada perairan alami biasanya jarang melebihi 0,1 $\mathrm{mg} / \mathrm{l}$. Kadar nitrat yang melebihi $5 \mathrm{mg} / \mathrm{l}$ menggambarkan terjadinya pencemaran antropogenik yang berasal dari aktifitas manusia dan tinja hewan.

Kecerahan perairan sangat dipengaruhi oleh sinar matahari yang masuk ke dalam perairan. Semakin tinggi intensitas cahaya matahari yang masuk ke dalam perairan maka semakin tinggi nilai kecerahan perairan tersebut. Makroalga membutuhkan sinar matahari untuk membantu proses fotosintesis. Hasil pengukuran di lokasi penelitian diperoleh kecerahan mencapai 100\%, dimana intensitas cahaya matahari yang masuk sampai ke dasar perairan. Kondisi tersebut sangat mendukung untuk pertumbuhan makroalga. Peran sinar matahari untuk membantu proses fotosintesis yang terjadi di dalam tubuh makroalga. Sebagaimana pernyataan Graham dan Wilcox 
(2000), penyerapan cahaya matahari dapat terjadi karena adanya pigmen fotosintesis dan pigmen asesoris. Pigmen asesoris berperan dalam menerima energi cahaya matahari untuk ditransfer ke klorofil.

Kedalaman perairan dapat mempengaruhi kepadatan dan distribusi makroalga. Makroalga yang hidup di dasar laut banyak terdapat di sepanjang pantai mulai dari zona pasang surut sedalam cahaya matahari dapat tembus. Hasil pengukuran kedalaman perairan di lokasi penelitian berkisar 10-270 cm, dimana masih dijangkau oleh penetrasi cahaya. Hal ini masih mendukung untuk kehidupan makroalga. Sebagaimana pernyataan Nontji (2007), di perairan yang jernih terdapat beberapa jenis alga yang dapat hidup sampai kedalaman $150 \mathrm{~m}$. Sedangkan untuk jenis makroalga tertentu pada perairan yang jernih dapat tumbuh hingga kedalaman 20-30 m.

Kecepatan arus mempengaruhi proses penyebaran spora dan daya rekat holdfast di perairan. Gerakan air memiliki peran sebagai faktor penyebar stadia reproduksi dan persporaan makroalga (Ruslin, 2006). Perairan yang tenang dapat menyebabkan spora dapat menempel dengan baik pada substrat. Kecepatan arus yang terukur di lokasi penelitian berkisar 0,021-0,048 m/dtk. Nilai kecepatan arus tersebut masih mendukung untuk pertumbuhan dan perkembangan makroalga. Hal ini sesuai dengan pernyataan Atmadja et al (1996), pergerakan air yang baik untuk pertumbuhan makroalga adalah 0,033-0,066 m/dtk.

\section{Kesimpulan}

Jumlah jenis makroalga yang ditemukan terdiri atas 25 spesies yang meliputi 11 ordo, 14 famili, 17 genus. Komposisi jenis makroalga didominasi oleh kelas chlorophyta (44\%), kelas phaeophyta (28\%) dan kelas rhodophyta (28\%). Kualitas perairan Pulau Hari masih berada dalam kisaran yang mendukung pertumbuhan makroalga.

\section{Daftar Pustaka}

Angka, S.L., Suhartono M.T. 2000. Bioteknologi Hasil Laut. Bogor PKSPL-(PB.

Atmadja, W.S., A. Kadi, Sulistijo, Rachmaniar. 1996. Pengenalan jenis-jenis rumput laut di Indonesia. Pusat Penelitian dan Pengembangan Oseanologi-LIPI, Jakarta
Statistik Daerah Propinsi Sulawesi Tenggara. 2017. Badan Pusat Statistik Propinsi Sulawesi Tenggara.

Dawes, CJ. 1981. Marine Botany. John Wiley and Sons. University of South Florida. New York.

Dawson, E.Y., 1966. Marine Botan. New York, Chicago, San Fransisco, Toronto, London Inc

Effendie, H. 2003. Telaah Kualitas Air Bagi Pengelolaan Sumberdaya dan Lingkungan Perairan. Kanisius. Yogyakarta.

Fadhillah, A. 2009. Studi Ekologi makroalga di Perairan Pantai Lakeba Kota Bau-Bau. Skripsi. Universitas Halu Oleo. Kendari.

Fitriah, IY. 2001. Studi Komunitas Rumput Laut di Perairan Pantai Bagian Barat Desa Torokeku Kecamatan Tinanggea Kabupaten Kendari Sulawesi Tenggara.

Hill, R., K.E. Ulstrup., P.J. Ralph. 2009. Temperature Include Change in Thylakoid Membrane Thermostability of Cultured, Freshly Isolated, and Expelled Zooxanthelae From Scleractinian Corals. Buletin of Marine Science 85 (3): 223-244.

Graham, L.E., L.W. Wilcox. 2000. Algae. Prentice Hall, inc. New York

Kadi, A. 2000. Rumput laut di perairan Kalimantan Timur Dalam: D.P. Praseno, W.S. Atnadja, I. Soepangat, Ruyitno, dan B.S. Soedibjo (eds.) Pesisir dan Pantai Indonesia IV. Pusat Penelitian dan Pengembangan Oseanologi-LIPI Jakarta

Kadi, A., S.A. Wanda. 1998. Rumput Laut (Alga), Jenis Reprduksi, Produk Budidaya dan Pasca Panen. Proyek Studi Potensi Sumberdaya Alam Indonesia. LIPI. Jakarta.

Kadi, A. 1996. Pengenalan Jenis Alga Hijau (Chlorophyta) Dalam Pengenalan jenisJenis Rumput Laut Indonesia. Puslitbang Oseanologi LIPI. Jakarta.

Kadi, A. dan W. S. Atmadja 1988. Rumput Laut (Algae) Jenis, Reproduksi, Produksi, Budidaya dan Pasca-panen. Seri Sumber Daya Alam 141. PuslitbangOseanologi.LIPI. Jakarta.

McNaughton, S.J., Wolf, L. 1990. Ekologi Umum. UGM Press. Yogyakarta.

Nontji, A. 2007. Laut Nusantara. Djambatan. Jakarta. 
Odum, E. P. 1993. Dasar-Dasar Ekologi. Edisi Ketiga. Gajah Mada University Press. Yogyakarta.

Papalia, S., Arfah, H. 2013. Produktivitas Biomassa Makroalga Di Perairan Pulau Ambalau, Kabupaten Buru Selatan. Jurnal Ilmu dan Teknologi Kelautan Tropis, 2 (5): 456-467.

Rusli, 2006. Tipologi Makroalga pada Ekosistem Terumbu Karang di Tiga Pulau Kawasan Kepulauan Seribu DKI Jakarta. IPB. Bogor.

Serdianti, N., I.M. Widiastuti. 2010. Pertumbuhan dan Produksi Rumput Laut Eucheuma cottonii pada Kedalaman Penanaman yang Berbeda. Media Litbang Sulteng III. 3(1): 21-26

Toni, 2006. Inventarisasi Jenis Makroalga di Pulau Sertung dan Pulau Sebesi, Selat Sunda, Lampung. Fakultas MIPA. Universitas Indonesia. Jakarta.

Tjitrosoepomo, G. 2005. Taksonomi Tumbuhan (Schizophyta, Thallophyta, Bryophyta, Pteridophyta). Yogyakarta. Gadjah Mada University Press.

Umasagi, R. 2001. Kepadatan, Pola Distribusi dan Keanekaragaman Rumput Laut di Perairan Pantai Desa Tanjung Tiram Kecamatan Moramo Kabupaten Kendari.

Wray, J.I. 1977. Calcarious algae. Developments in Palaentology and Stratigraphy. Amsterdam. Elsevier Vol 4.

Xiong, I., J.K. Zhu. 2002. Salt Tolerance in The Arabidopsis. American Society of Plant Biologists.

www.algaebase.org. Database of Information on Alga That Includes Terrestrial, Marine and Freswater Organism. Diakses tanggal S Agustus - 20 September 2016. 